\title{
Corrigendum: Comparison of Personal, Social and Academic Variables Related to University Drop-out and Persistence
}

\author{
Ana Bernardo ${ }^{1 *}$, María Esteban $^{1 *}$, Estrella Fernández ${ }^{1}$, Antonio Cervero $^{2}$, Ellián Tuero $^{1}$ \\ and Paula Solano ${ }^{1}$
}

${ }^{1}$ Psychology Department, University of Oviedo, Oviedo, Spain, ${ }^{2}$ Department of Education, University of Oviedo, Oviedo, Spain

Keywords: higher education, university drop-out, academic performance, academic adaptation, social adaptation

\section{OPEN ACCESS}

Edited and reviewed by: José Carlos Núñez, Universidad de Oviedo Mieres, Spain

${ }^{*}$ Correspondence: Ana Bernardo bernardoana@uniovi.es María Esteban

maria_esteban_garcia@hotmail.com

Specialty section:

This article was submitted to

Educational Psychology,

a section of the journal

Frontiers in Psychology

Received: 27 January 2017

Accepted: 24 July 2017

Published: 02 August 2017

Citation:

Bernardo A, Esteban M, Fernández E,

Cervero A, Tuero $E$ and Solano $P$

(2017) Corrigendum: Comparison of Personal, Social and Academic

Variables Related to University

Drop-out and Persistence.

Front. Psychol. 8:1355

doi: 10.3389/fpsyg.2017.01355

\section{A corrigendum on}

Comparison of Personal, Social and Academic Variables Related to University Drop-out and Persistence

by Bernardo, A., Esteban, M., Fernández, E., Cervero, A., Tuero, E., and Solano, P. (2016). Front. Psychol. 7:1610. doi: 10.3389/fpsyg.2016.01610

There is an omission on the funding section, as authors specified the project funds, but did not mention additional funds. Therefore, where in the original article says;

"Alfaguia Project was developed thanks to the European Union funding (DCI-ALA/2010/94)." Should say:

"Alfaguia Project was developed thanks to the European Union funding (DCI-ALA/2010/94). In addition, our research activity is also granted by European Regional Development Funds (European Union and Principality of Asturias) through the Science, Technology and Innovation Plan (GROUPIN14-100 and GROUPIN14-053)."

The authors apologize for any caused inconvenience. This omission does not affect the scientific conclusions of the article.

Conflict of Interest Statement: The authors declare that the research was conducted in the absence of any commercial or financial relationships that could be construed as a potential conflict of interest.

The handling Editor declared a shared affiliation, though no other collaboration, with the authors $\mathrm{AB}, \mathrm{ME}, \mathrm{EF}, \mathrm{AC}$, $\mathrm{ET}$, and PS and states that the process nevertheless met the standards of a fair and objective review.

Copyright (c) 2017 Bernardo, Esteban, Fernández, Cervero, Tuero and Solano. This is an open-access article distributed under the terms of the Creative Commons Attribution License (CC BY). The use, distribution or reproduction in other forums is permitted, provided the original author(s) or licensor are credited and that the original publication in this journal is cited, in accordance with accepted academic practice. No use, distribution or reproduction is permitted which does not comply with these terms. 